\title{
The impact of collaborative model assisted by Google Classroom to improve students' creative thinking skills
}

\author{
Jumadi Jumadi $^{1}$, Riki Perdana ${ }^{2}$, Muhammad Helmi Hariadi ${ }^{3}$, Warsono Warsono ${ }^{4}$, Andi Wahyudi ${ }^{5}$ \\ 1,3,4 Department of Physics Education, Universitas Negeri Yogyakarta, Indonesia \\ ${ }^{2,5}$ Faculty of Teacher Training and Education, Universitas Alma Ata, Indonesia
}

\section{Article Info \\ Article history: \\ Received Sep 3, 2020 \\ Revised Mar 21, 2021 \\ Accepted Apr 10, 2021}

\section{Keywords:}

Creative thinking

Google Classroom

Project-collaborative

\begin{abstract}
Indonesian students' creative thinking skill is still at a low level. This study aimed to examine the effectiveness of project collaborative model assisted by Google Classroom (PjCM-GC) in improving students' creative thinking skills. This research explored the differences between students who learned through the demonstration model (DM), project collaborative model (PjCM), and project collaborative model assisted by Google Classroom (PjCM-GC). It was a quasi-experimental with pre and post-test design. The population of this research was students at Senior High School, Lombok Timur-Indonesia. Random sampling technique was employed in this study. The sample was 86 science students grade XI (15-16 ages) who studied in SMAN 1 Aikmel. The data analyzed by paired-sample t-test, comparative-descriptive analysis, and ANOVA mixed design using SPSS 24. The study showed that The PjCM-GC group had a significant difference in the level of creative thinking skills (sig .0000). The PjCM-GC was the most effective model to improve the skills with a gain score of .47 (medium). Learning with the PjCM-GC model can be an alternative for policymakers and teachers to solve the problems of creative thinking.
\end{abstract}

This is an open access article under the CC BY-SA license.

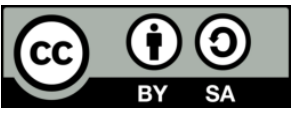

\section{Corresponding Author:}

Riki Perdana

Faculty of Teacher Training and Education

Universitas Alma Ata

J1. Brawijaya, Bantul, D.I. Yogyakarta, Indonesia

Email: rikiperdana@almaata.ac.id

\section{INTRODUCTION}

In Indonesia, most of the student has creative thinking skill at a low level. Their ideas are still in the form of trial and error, not systematic, not detailed, and there are still many obstacles in solving a problem and preparing steps for solving problems [1]. According to Zubaidah, et al. [2], the mean score of students on creative thinking skills only 23.44 from 100. Another study shows that the score of students' creative thinking skill in their study only 34 from 100 [3]. According to Hakim, et al. [4] the score of students on aspect creative thinking only 34.22 (fluency), 40.96 (flexibility), 34.33 (elaboration) and 35.45 (originality).

Creative thinking is domains of creativity that be divided into several categories, namely, creative person, creative press, creative process, and creative products [5]. The Creative person related to individual habits in carrying out actions, processes, or creation (creative behavior). The creative press related to the attitudes carried out by individuals that produce a creative product. The creative process related to how individuals assimilate information and ideas into creative products. The creative product is the result of efforts or creative actions from individuals resulting from information or ideas [6]. 
There are two ways that can be done to increase creativity, that is through the identification of personal talents and the enthusiasm of students to build relationships in producing something; and through learning creative skills [7]. Creative thinking skills are included in process creativity, which is a persons' way of processing information and ideas [8]. The characteristic of creative thinking is divergent by developing ideas or information and trying to apply them to problems [9]. Creative thinking skills consist of four indicators, that is fluency, flexibility, elaboration, and originality.

One of the learning models that can be used to improve creative thinking skill is project-based learning $(\mathrm{PjBL})$. PjBL students are more flexible in adapting their knowledge to new problems and conceptual questions compared to conventional students [10]. PjBL also provides opportunities for students to promote their achievement [11]. PjBL starts with assignments that must be completed and leads to the production of the final product so that learning is driven by the final product [12]. Students are encouraged to present the knowledge gained through "driving questions", then directed to make products [13]. The characteristics of PjBL are enabling students to have creativity, develop thinking skills, direct to access and show information, and encourage them to work cooperatively [14]. It engenders mutual responsibility, recognition as team members, and collaboration between students [15]. Students also receive PjBL learning in the form of collaborative learning or teamwork [16], and collaborating on projects improves student teamwork skills [17]. So, in PjBL, students also make a collaborative learning process.

Collaborative learning give many positive impacts on the learning process. Collaborative learning can contribute positively to students' motivation [18], logical thinking skills [19]. In this learning, students in groups are responsible for teamwork even though they have different learning [20]. In a collaborative, learning process through many theories of how people interact through and with computing machines so this form of collaborative learning is important for both [21]. According to Sompong [22], teacher possibly integrated using both collaborative learning and project-based learning for enhancing the competence of creative thinking skills by using the Learning Management Systems eLearning Courseware. In this study, Google Classroom was chosen to be one of them.

Google Classroom provides a set of powerful features that make it an ideal tool for use with students and is considered one of the best platforms for improving teacher workflow [23]. It can improve class dynamics, student participation, and learning [24]. Google Classroom can streamline the assignments, promote paperless learning, foster good communication, and enhance collaboration so that teaching is more meaningful and productive [25]. In Google Classroom, a teacher can create a class for a specific subject and can also include more teachers for the same subject, thus helping students to get additional ideas online [26].

The purpose of this study is to describe the significances of the difference between learned students using the PjCM-GC, PjCM, and demonstration models, and the effectiveness of these learning models in improving students' creative thinking skills. However, the PjCM-GC model has never been applied or previously applied to teaching in the class. Therefore, a learning model is needed that can enhance the learning process, especially in creative thinking skills.

\section{RESEARCH METHOD}

This study was a quasi-experimental design in which the objective study was observing the creative thinking skill of students using the demonstration model, project collaborative model (PjCM), and Project collaborative model with Google Classroom (PjCM-GC). This PjCM-GC model, however, is the new learning model and has not been applied at the class in improving students' creative thinking skills. The research design was pre-test and post-test control group design. The aimed of the research was to know the students' creative thinking skills between the PjCM-GC and PjCM model as the experimental groups and the demonstration model as the control group. Hence, these research objectives have been describing the significances of the difference between learned students using demonstration model, PjCM, and PjCM-GC and the effectiveness of all models. All of learning model was developed in this study and were taught by a teacher who employed in research location. To train this teacher, we give the teacher a lesson plan, which will guide the teacher to implemented model according to the expected model.

Sample of this study was students in the same school with selected through random sampling. There were 86 science students grade XI (15-16 age). There are two classes for the PjCM group. The first class was only taught with PjCM model learning which consisted of a total of 28 (6 males and 22 females) students. The second class was based on the PjCM-GC learning model consisting of a total of 28 (6 males and 22 females) students. The third class is only taught with the demonstration model consisting of 30 (8 males and 22 females). All classes are given eight sessions ( $8 \times 45$ minutes). The first competency of all groups would be the same with the homogeneity test of the variance from the pre-test data of each group.

The research tools used are: 1) Demonstration, $\mathrm{PjCM}$, and PjCM-GC matrices that contain learning competencies based on topics, activities, and assessments given to students during the study period. It has 
been validated by professional experts; 2) Guide-lines for Teach-ers which consist of detailed lesson plans; 3) Learning materials in the form of other modules developed by researchers; 4) Test creative thinking skills. Students are asked to complete 8 questions according to aspects of creative thinking skills. The instrument of creative thinking skills was developed through analysis of content and construct validity, and reliability. The items are also validated by professional experts and empirical tests. For the professional judgment, we used content validity ratio (CVR) [27]. Not only from the CVR score, but the validity of the creative thinking ability test was also assessed by Aiken's V to assess the aspects of content, construction, and language. For the empirical test, we got the validity and reliability scale. Based on the analysis result, all items were reliable with the reliability scale .96 . Assessment of student skills based on their score. Table 1 shows the skill level of students based on their test results.

Table 1. Level of students skill

\begin{tabular}{cc}
\hline Range & Level \\
\hline $0.00-0.39$ & Very low \\
$0.40-1.39$ & Low \\
$1.40-2.09$ & Average \\
$2.10-2.49$ & High \\
$2.50-3.00$ & Very high \\
\hline
\end{tabular}

All students were given eight items in pre-tests and post-test. The results were used to identify the level of students' creative thinking skills after they were exposed to three different models. The aspects of creative thinking skills in this study were fluency, flexibility, originality, elaboration. There was a professor, two doctors, two professional teachers, and two postgraduate students who assessed all of the items. After the material assessment and based on expert recommendations, the final question is shown as in Table 2.

Table 2. Items of creative thinking skill

\begin{tabular}{cc}
\hline Item & Aspect of creative thinking skill \\
\hline 1,5 & Fluency \\
2,6 & Flexibility \\
3,7 & Originality \\
4,8 & Elaboration \\
\hline
\end{tabular}

In this study, we used SPSS 24 to analyze data. The profile of students' skills was analyzed by descriptive statistics. Analyzes were performed using paired sample t-tests on the results of tests conducted by students to determine differences in the quality of their creative thinking skills. ANOVA analysis of mixed designs was used to determine differences in the results of creative thinking skills in the demonstration, PjCM, and PjCM-GC groups. Finally, to determine the effectiveness level of each model, we use the gain score analysis with Hake's equation [28]:

$$
\operatorname{Gain}(g)=\frac{\bar{X}_{\text {posttest }}-\bar{X}_{\text {pretest }}}{\text { maximum score }-\bar{X}_{\text {pretest }}}
$$

Where $\bar{X}_{\text {posttest }}$ and $\bar{X}_{\text {pretest }}$ is the average score from the pre and post-test. Level of effectiveness is based on the above equation as shown in Table 3.

Table 3. Gain score

\begin{tabular}{cc}
\hline Item & Level of effectiveness \\
\hline$g<.3$ & Low \\
$.7>g \geq .3$ & Medium \\
$g \geq .7$ & High \\
\hline
\end{tabular}

\section{RESULTS AND DISCUSSION}

\subsection{Demonstration group}

Students were given eight questions based on four aspects of creative thinking skills. Table 4 shows the results of their answers and their skill level. It shows that students' level in this group showed very low levels of creative thinking skills. These results show that their skills related to creative thinking skills have 
not been improved. The quality of students in the demonstration Group before and after learning is shown in Table 5. A paired sample t-test is used to see whether there are significant differences in creative thinking skills before and after the learning process as shown in Table 6.

Table 4. The level of creative thinking skill of demonstration group based on the aspect

\begin{tabular}{ccccccc}
\hline \multirow{2}{*}{ Aspect } & \multicolumn{2}{c}{ Pre-test } & \multirow{2}{*}{ Description } & \multicolumn{2}{c}{ Post-test } & \multirow{2}{*}{ Description } \\
\hline Fluency & .85 & .81 & Low & 1.55 & .81 & Average \\
Flexibility & .83 & .92 & Low & 1.20 & .77 & Low \\
Originality & .55 & .86 & Low & 1.13 & .67 & Low \\
Elaboration & .17 & .38 & Very low & .95 & .91 & Low \\
Overall & .60 & .30 & Low & 1.21 & .22 & Low \\
\hline
\end{tabular}

Note: 0-.39=Very low; .40-1.39=Low; $1.40-2.09=$ Average; $2.10-2.49=H i g h ; 2.50-4.00=$ Very high

Table 5. Level of creative thinking skill of the demonstration group before and after

\begin{tabular}{ccccc}
\hline Level & \multicolumn{2}{c}{ Before $(\mathrm{n}=30)$} & \multicolumn{2}{c}{$\operatorname{After}(\mathrm{n}=30)$} \\
& $\mathrm{f}$ & $\%$ & $\mathrm{f}$ & 0 \\
\hline Very low & 9 & 30 & 21 & 70 \\
Low & 20 & 3.33 & 8 & 26.67 \\
Average & 1 & 0 & 0 & 0 \\
High & 0 & 0 & 1 & 3.33 \\
Very high & 0 & Mean=1.29(Low), SD=.42 \\
Overall & Mean=.64 (Low), SD=.39
\end{tabular}

Note: 0-.39=Very low; .40-1.39=Low; 1.40-2.09=Average; $2.10-2.49=H i g h ; 2.50-4.00=$ Very high

Table 6. Paired sample t-test of demonstration group

\begin{tabular}{lccccc} 
& Mean & SD & t-value & df & Sig \\
\hline Pre-test & .65 & .39 & 7.656 & 2 & .000 \\
Post-test & 1.31 & .42 & & 9 & \\
\hline
\end{tabular}

\subsection{Project collaborative model $(\mathrm{PjCM})$ group}

Students were given eight questions based on four aspects of creative thinking skills. Stu-dent answers are analyzed and the results are shown in Table 7. Table 7 shows that students in the PjCM group showed the quality of students' skills. The level of students' creative thinking skills in PjCM Group before and after they were taught with this model is shown in Table 8. A paired sample t-test was used to determine differences in the results of creative thinking skills in this group. The results are shown in Table 9.

Table 7. The level of creative thinking skill of PjCM group based on the aspect

\begin{tabular}{ccccccc}
\hline \multirow{2}{*}{ Aspect } & \multicolumn{2}{c}{ Pre-test } & \multirow{2}{*}{ Description } & \multicolumn{2}{c}{ Post-test } & \multirow{2}{*}{ Description } \\
& Mean & SD & Mean & SD & \\
\hline Fluency & .82 & .67 & Low & 1.80 & .30 & Average \\
Flexibility & .98 & .93 & Low & 1.20 & .68 & Low \\
Originality & .66 & .50 & Low & 1.32 & 1.16 & Low \\
Elaboration & .30 & .46 & Very low & 1.16 & 1.63 & Low \\
Overall & .69 & .34 & Low & 1.37 & .51 & Low
\end{tabular}

Note: 0-.39=Very low; .40-1.39=Low; 1.40-2.09=Average; $2.10-2.49=$ High; $2.50-4.00=$ Very high

Table 8. Level of creative thinking skill of the PjCM group before and after

\begin{tabular}{ccccc}
\hline Level & \multicolumn{2}{c}{ Before $(\mathrm{n}=28)$} & \multicolumn{2}{c}{ After $(\mathrm{n}=28)$} \\
& $\mathrm{f}$ & 17.85 & 1 & 3.57 \\
\hline Very low & 5 & 82.15 & 13 & 46.42 \\
Low & 23 & 0 & 13 & 46.42 \\
Average & 0 & 0 & 1 & 3.57 \\
High & 0 & 0 & 0 & 0 \\
Very High & 0 & Mean=1.37 (Low), SD=.39 \\
Overall & Mean=.69 (Low), $S D=.30$ &
\end{tabular}

Note: 0-.39=Very low; .40-1.39=Low; 1.40-2.09=Average; $2.10-2.49=H i g h ; 2.50-4.00=$ Very high 
Table 9. Paired sample t-test of PjCM group

\begin{tabular}{lccccc}
\hline & Mean & SD & t-value & df & Sig \\
\hline Pre-test & .69 & .30 & -7.574 & 27 & .000 \\
Post-test & 1.37 & .40 & & & \\
\hline
\end{tabular}

\subsection{Project collaborative model assisted by Google Classroom (PjCM-GC) group}

Students were given eightquestions based on four aspects of creative thinking skills. Stu-dent answers are analyzed and the results are shown in Table 10. The quality of creative thinking that is still very low in the PjCM-GC group. It shows that their skills related to creative thinking have not been improved. The level of students' creative thinking skills in PjCM-GC Group before and after they were taught with this model is shown in Table 11. A paired sample t-test was used to determine differences in the results of creative thinking skills in this group as shown in Table 12.

Table 10. The level of creative thinking skill of PjCM-GC group based on the aspect

\begin{tabular}{ccccccc}
\hline \multirow{2}{*}{ Aspect } & \multicolumn{2}{c}{ Pre-test } & \multirow{2}{*}{ Description } & \multicolumn{2}{c}{ Post-test } & \multirow{2}{*}{ Description } \\
& Mean & SD & & Mean & SD & \\
\hline Fluency & .91 & .82 & Low & 2.00 & .87 & Average \\
Flexibility & 1.04 & .84 & Low & 2.11 & .84 & High \\
Originality & .30 & .50 & Very Low & 1.45 & .89 & Average \\
Elaboration & .27 & .66 & Very Low & 1.43 & .78 & Average \\
Overall & .63 & .45 & Low & 1.75 & .34 & Average \\
\hline
\end{tabular}

Note: 0-.49=Very low; .50-1.49=Low; 1.50-2.49=Average; $2.50-3.49=H i g h ; 3.50-4.00=$ Very high

Table 11. Level of creative thinking skill of the PjCM-GC group before and after

\begin{tabular}{ccccc}
\hline Level & \multicolumn{2}{c}{ Before $(\mathrm{n}=28)$} & \multicolumn{2}{c}{ After $(\mathrm{n}=28)$} \\
\hline Very low & 5 & 17.85 & 1 & 3.57 \\
Low & 23 & 82.15 & 8 & 28.57 \\
Average & 0 & 0 & 10 & 35.71 \\
High & 0 & 0 & 5 & 17.85 \\
Very high & 0 & 0 & 3 & 10.71 \\
Overall & Mean=.63 (Low), SD=.29 & Mean=1.74 (Average), SD=.63
\end{tabular}

Table 12. Paired sample t-test of the PjCM-GC group

\begin{tabular}{lccccc}
\hline & Mean & SD & t-value & df & Sig \\
\hline Pre-test & .63 & .29 & -8.648 & 27 & .000 \\
Post-test & 1.74 & .64 & & & \\
\hline
\end{tabular}

\subsection{Comparison of all group}

In this study, we use ANOVA Mixed Design to determine the greatest influence be-tween demonstration, PjCM, and PjCM-GC model on students' creative thinking skills. The results as shown as in Table 13. A comparison of all groups was also analyzed using the gain score. The results are presented in Table 14. It shows that there is an increase in all groups. However, the level of effectiveness of all groups is still low.

Table 13. ANOVA mixed design analysis of all group

\begin{tabular}{llc}
\hline \multicolumn{1}{c}{ Group } & Sig & Partial eta square \\
\hline Demonstration $(n=30)$ & .000 & .342 \\
PjCM $(n=28)$ & .000 & .339 \\
PjCM-GC $(n=28)$ & .000 & .582 \\
\hline
\end{tabular}

Table 14. Gain score

\begin{tabular}{lcccc}
\hline \multicolumn{1}{c}{ Group } & Mean of pre-test & Mean of post-test & Gain score & Description \\
\hline Demonstration $(N=30)$ & .65 & 1.31 & .28 & Low \\
PjCM $(N=28)$ & .69 & 1.37 & .29 & Low \\
PjCM-GC $(N=28)$ & .63 & 1.74 & .47 & Medium \\
\hline
\end{tabular}

Note: $g<.3=$ Low, $.30 \leq g \leq .70=$ Medium; $g>.70=$ high

Int J Eval \& Res Educ, Vol. 10, No. 2, June 2021: 396 - 403 
The mean of the creative thinking skills of students in the demonstration group before the learning process was low (mean=.60, $\mathrm{SD}=.30$ ). Among eight questions given, the lowest student answers are in aspect elaboration (mean=.17, $\mathrm{SD}=.38$ ). Meanwhile, the highest mean score of student answer is aspect fluency .85 (low). The creative thinking skills in the demonstration group was at a very low (30\%), low (66.67\%), and average (3.33) before the learning process. In general, based on the pre-test results students in this group had low levels (mean=.60; $\mathrm{SD}=.30$ ). There are no students who showed a high and very high level.

The quality of creative thinking skills based on the post-test score still was at a low level $($ mean $=1.21 ; \mathrm{SD}=.22)$. In particular, most $(70 \%)$ students showed at low levels, $26.67 \%$ on average, and only $(3.33 \%)$ at a very high level. It should be considered that there is a decrease in the number of students at very low levels and an increase in the number of students at the low, average, and high level. Overall, demonstration models can improve students' achievement. There are differences in the mean score of .66 points (pre and post-test) and there are significant differences based on the results of the analysis with paired sample t-test.

For the PjCM group the mean of the creative thinking skills of students was at a low level (mean=.69, $\mathrm{SD}=.34$ ) in the pre-test. Among the 8 questions given, the lowest student answers are in aspect elaboration with mean=.30 (low). Meanwhile, the highest student answer is aspect flexibility (mean=.98; $\mathrm{SD}=.93$ ) still at low level. The quality of creative thinking skills that are still low level in the group shows that their skills have not been improved.

The quality of creative thinking skills in the PjCM group was at a low level $(21.875 \%)$ and few $(17.85 \%)$ of students showed a low level and there are no students at high and very high level before learning process. In general, students in this group had low levels (mean=.69; $\mathrm{SD}=.30$ ) based on pre-test. After the learning process, the quality of students' creative thinking skills in $\mathrm{PjCM}$ group was at low levels $($ mean=1.37; $\mathrm{SD}=.39)$. In particular, few students $(3.57 \%)$ at very low, $46.42 \%$ of students showed at low and average levels, only $3.57 \%$ at a high level. It should be considered that there is a decrease in the number of students at low and very low levels. However, there is an increase in the number of students at average and high levels. Based on the test, there is significant differences in creative thinking skills in PjCM group sig $.000<.005$. There is a difference in the mean score of .68 points (pre and post-test). It shows that PjCM model can improve the students' achievement in creative thinking.

For the PjCM-GC group, students in this group showed low levels of students' creative thinking skills (mean=.63; $\mathrm{SD}=.45$ ). Among eight questions given, the lowest student answers are in aspect elaboration with mean=.27 (low). Meanwhile, the highest student answer is aspect flexibility $(\mathrm{mean}=1.04)$ but it is still at a low level.

Before the learning process, the number of students at each level was at a very low (17.85\%) and a low level $(82.15 \%)$. There are no students at average, high and very high levels. In general, students in this group had low levels based on the pre-test score and there are no students at a high level. The quality of students' creative thinking skills after the learning process with PjCM-GC model was at average levels (mean=1.74; $\mathrm{SD}=.63$ ). After the learning process, $10.71 \%$ of students showed at very high, $17.85 \%$ at high, $35.71 \%$ on average, $28.57 \%$ at low, and only $3.57 \%$ at very low levels. It should be considered that there is an increase in the number of students at average, high, and very high level. Overall, there has been a decrease in the number of students at low and very low levels. Based on the test, there is a significant differences about creative thinking skill in PjCM-GC group. There is a difference in the mean of 1.11 points (pre and post-test). It indicates that the PjCM-GC model can improve their level.

For the comparison of three learning models in this study, based on the partial eta square on the ANOVA mixed design test, the demonstration model can enhance the students' creative thinking skills by $34.2 \%$, PjCM model=33.9\% and PjCM-GC model=58.2\%. The result indicates that the PjCM-GC model is the most effective to enhance students' creative thinking skills than $\mathrm{PjCM}$ and demonstration model. This result also can be seen in Figure 1. It shows that PjCM-GC model can improve the creative thinking skill of the students more than the demonstration and PjCM model. Based on the gain score, The PjCM-GC model is the highest impact with a gain score of .47 (medium) in enhancing students' creative thinking skills. While the demonstration only .28 (low) and PjCM model only .29 (low).

Based on the analysis, the PjCM-GC has a positive impact on creative thinking skills. This result is similar to Chen, et al. [29], that project-based learning was able to encourage students' creative thinking, especially in terms of flexibility and fluency. According to Gunawan, et al. [30] the implemented PjBL had a higher increase in creativity compared to the control class, especially aspects of verbal creativity which was higher than that of figural creativity. Project-Based Programs were effective for creative thinking skills because there was an increase in aspects of fluency, originality, and imagination in their study [31]. In project-based learning, students can create new products or processes that help the learning and teaching of a subject to achieve student creativity [32]. 
Collaborative learning also give a positive impact on the PjCM-GC model in this study. This finding is similar to Hobri, et al. [33] that the creative thinking skills of students in the experimental group with the collaborative learning project model are better than the control group. According to Kusumawati, et al. [34] the integrated collaborative learning based on Lesson Study for Learning Community can improve students' creative thinking. Through collaborative learning, students are trained to be responsible for the learning of other students, so that the success of a student can be a helper for other students, they also get used to asking their friends when they have problems in the learning process [33].

According to Sompong [22], Project-based collaborative learning can produce creative output at a high level, maintain students' collaborative learning, even most of them achieve certain content. The PjCMGC give a positive impact on creative thinking skills because it also learning by Google Classroom. There are the positive impact where the students' creative thinking skills were higher than the specified criteria, namely $70 \%$ and were higher than before learning with Google Classroom at a significant level of 0.05 [35].

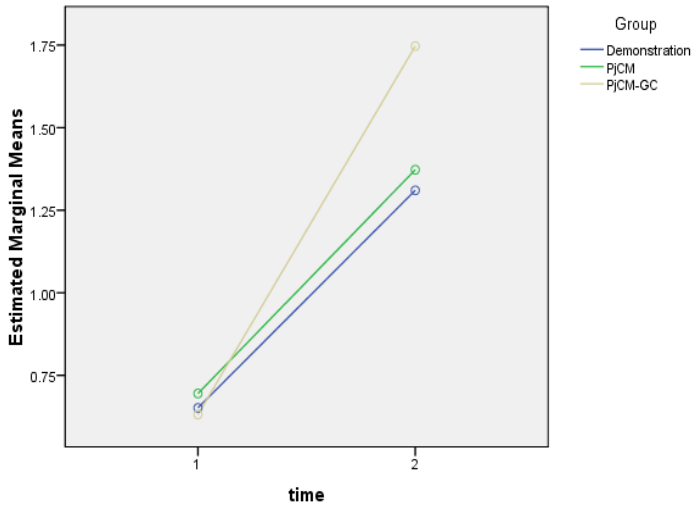

Figure 1. The differences of creative thinking skill all groups

\section{CONCLUSION}

The PjCM-GC model is more powerful in improving student's creative thinking skills than the $\mathrm{PjCM}$ and Demonstration model. The PjCM-GC learning model can be regarded as the solution to solve the problems of students' creative thinking skills. Hence, the final results of the study indicate that there is a significant difference (sig .000) between the PjCM-GC, PjCM, and demonstration groups. In addition, the PjCM-GC model had also proven to be effective for teaching creative thinking skills which shows a significant difference (sig .000) between the pretest and post-test.

\section{ACKNOWLEDGEMENTS}

This research was supported by the Indonesian Ministry of Education and Higher Education and the Postgraduate Program of Yogyakarta State University.

\section{REFERENCES}

[1] L. Puspitasari, A. In'am, and M. Syaifuddin, "Analysis of Students' Creative Thinking in Solving Arithmetic Problems,” Int. Electron. J. Math. Educ., vol. 14, no. 1, pp. 49-60, 2018.

[2] S. Zubaidah, N. M. Fuad, S. Mahanal, and E. Suarsini, "Improving creative thinking skills of students through Differentiated Science Inquiry integrated with mind map," J. Turkish Sci. Educ., vol. 14, no. 4, pp. 77-91, 2017.

[3] M. Nuswowati and M. Taufiq, "Developing creative thinking skills and creative attitude through problem based green vision chemistry environment learning," J. Pendidik. IPA Indones., vol. 4, no. 2, pp. 170-176, 2015.

[4] A. Hakim, L. Liliasari, A. Setiawan, and G. A. P. Saptawati, "Interactive Multimedia Thermodynamics To Improve Creative Thinking Skill of Physics Prospective Teachers," J. Pendidik. Fis. Indonesia, vol. 13, no. 1, pp. 33-40, 2017, doi: 10.15294/jpfi.v13i1.8447.

[5] S. Garcês, M. Pocinho, S. N. De Jesus, and J. Viseu, "The impact of the creative environment on the creative person, process, and product," Aval. Psicol., vol. 15, no. 2, pp. 169-176, 2016, doi: 10.15689/ap.2016.1502.05.

[6] P. J. Silvia, R. E. Beaty, E. C. Nusbaum, K. M. Eddington, H. Levin-Aspenson, and T. R. Kwapil, "Everyday creativity in daily life: An experience-sampling study of 'little c' creativity," Psychol. Aesthetics, Creat. Arts, vol. 8, no. 2, pp. 183-188, 2014, doi: 10.1037/a0035722.

Int J Eval \& Res Educ, Vol. 10, No. 2, June 2021: 396 - 403 
[7] P. Torrance, "The nature of creativity as manifest in its testing," in R. J. Sternberg, Ed., The nature of creativity: Contemporary psychological perspectives. Cambridge University Press, 1988, pp. 43-75.

[8] K. H. Kim, "The Torrance Tests of Creative Thinking-Figural or Verbal: Which One Should We Use?" Creat. Theor. - Res. - Appl., vol. 4, no. 2, pp. 302-321, 2017.

[9] D. Zabelina, A. Saporta, and M. Beeman, "Flexible or leaky attention in creative people? Distinct patterns of attention for different types of creative thinking," Mem. Cogn., vol. 44, no. 3, pp. 488-498, 2016.

[10] M. E. Beier, M. H. Kim, A. Saterbak, V. Leautaud, S. Bishnoi, and J. M. Gilberto, "The effect of authentic projectbased learning on attitudes and career aspirations in STEM," J. Res. Sci. Teach., vol. 56, no. 1, pp. 1-23, 2019, doi: $10.1002 /$ tea.21465.

[11] O. Kizkapan and O. Bektas, "The effect of project based learning on seventh grade students' academic achievement," Int. J. Instr., vol. 10, no. 1, pp. 37-54, 2017, doi: 10.12973/iji.2017.1013a.

[12] J. Uziak, "A project-based learning approach in an engineering curriculum," Glob. J. Eng. Educ., vol. 18, no. 2, pp. 119-123, 2016.

[13] V. Basilotta Gómez-Pablos, M. Martín del Pozo, and A. García-Valcárcel Muñoz-Repiso, "Project-based learning (PBL) through the incorporation of digital technologies: An evaluation based on the experience of serving teachers," Comput. Human Behav., vol. 68, pp. 501-512, 2017, doi: 10.1016/j.chb.2016.11.056.

[14] C. L. Chiang and H. Lee, "The Effect of Project-Based Learning on Learning Motivation and Problem-Solving Ability of Vocational High School Students," Int. J. Inf. Educ. Technol., vol. 6, no. 9, pp. 709-712, 2016.

[15] A. M. Mahasneh and A. F. Alwan, "The effect of project-based learning on student teacher self-efficacy and achievement," Int. J. Instr., vol. 11, no. 3, pp. 511-524, 2018, doi: 10.12973/iji.2018.11335a.

[16] R. Pinter and S. M. Cisar, "Measuring Team Member Performance in Project Based Learning," J. Appl. Tech. Educ. Sci., vol. 8, no. 4, pp. 22-34, 2018.

[17] E. H. Fini, F. Awadallah, M. M. Parast, and T. Abu-Lebdeh, "The impact of project-based learning on improving student learning outcomes of sustainability concepts in transportation engineering courses," Eur. J. Eng. Educ., vol. 43 , no. 3 pp. $473-488,2018$.

[18] A. M. O. Colon, I. M. M. Galiano, and M. J. Colmenero-Ruiz, "Impact of the flipped classroom model and collaborative learning in childhood teaching university degree," J. E-Learning Knowl. Soc., vol. 13, no. 3, pp. 131-143, 2017.

[19] H. J. M. Ramirez and S. L. C. Monterola, "Co-creating scripts in computer-supported collaborative learning and its effects on students' logical thinking in earth science," Interactive Learning Environments, 2019, doi: 10.1080/10494820.2019.1702063.

[20] K. Singsungnoen and P. Piriyasurawong, "The Design of a Prototype of Collaborative Learning for Creative Thinking of Junior Programmer," Int. J. Appl. Comput. Technol. Inf. Syst., vol. 6, no. 1, pp. 11-15, 2016.

[21] G. Stahl, T. Koschmann, and D. Suthers, "Computer-supported collaborative learning," in R. K. Sawyer, Ed., The Cambridge Handbook of the Learning Sciences, 2nd Ed. Cambridge University Press, 2014, pp. 409-426.

[22] N. Sompong, "Learning management system for creative thinking skill development with collaborative learning of the graduate students in Kasetsart university," Int. J. Environ. Sci. Educ., vol. 13, no. 6, pp. 527-532, 2018.

[23] S. Iftakhar, "Google classroom: what works and how," J. Educ. Soc. Sci., vol. 3, no. 1, pp. 12-18, 2016.

[24] K. R. Heggart and J. Yoo, "Getting the most from google classroom: A pedagogical framework for tertiary educators," Aust. J. Teach. Educ., vol. 43, no. 3, pp. 140-153, 2018.

[25] R. J. M. Ventayen, K. L. Estira, M. J. De Guzman, C. M. Cabaluna, and N. N. Espinosa, "Usability Evaluation of Google Classroom: Basis for the Adaptation of GSuite E-Learning Platform," Asia Pacific J. Educ. Arts Sci., vol. 5, no. 1 , pp. 47-51, 2018.

[26] S. Bhat, R. Raju, A. Bikramjit, and R. D'souza, "Leveraging e-learning through google classroom: A usability study," J. Eng. Educ. Transform., vol. 31, no. 3, pp. 129-135, 2018.

[27] C. H. Lawshe, “A quantitative approach to content validity," Pers. Psychol., vol. 28, no. 4, pp. 563-576, 1975.

[28] R. R. Hake, R. Wakeland, Bhattacharyya, A, and R. Sirochman, "Assessment of individual student performance in an introductory mechanics course," AAPT Announc., vol. 24, no. 4, p. 76, 1994.

[29] S. Y. Chen, C. F. Lai, Y. H. Lai, and Y. S. Su, "Effect of project-based learning on development of students' creative thinking," Int. J. Electr. Eng. Educ., pp. 1-19, Jun. 2019, doi: 10.1177/0020720919846808.

[30] G. Gunawan, H. Sahidu, A. Harjono, and N. Suranti, "The effect of project based learning with virtual media assistance on student's creativity in physics," Cakrawala Pendidik., no. 2, pp. 167-179, 2017, doi: 10.21831/cp.v36i2.13514.

[31] F. A. Al-Hassawi, F. Y. Al-Zaghul, and I. A. R. Al-Jassim, "The Effect of A Project- Based Program to Develop The of Critical and Creative Thinking Skills," Int. J. Soc. Sci., vol. 6, no. 1, pp. 306-323, 2020.

[32] T. Sookpatdhe and S. Soranastaporn, "Simulation and project based learning for developing creativity: From classroom to real life," ThaiSim J. Learn. Dev., vol. 1, no. 1, pp. 85-105, 2016.

[33] Hobri, et al., "The students' creative thinking ability in accomplishing collaborative learning-based open-ended questions," in IOP Conference Series: Earth and Environmental Science, vol. 243, 2019, pp. 1-10.

[34] R. Kusumawati, Hobri, and A. F. Hadi, "Implementation of integrated inquiry collaborative learning based on the lesson study for learning community to improve students' creative thinking skill," Journal of Physics: Conference Series, vol. 1211, 2019, pp. 1-12.

[35] P. Boonsong and P. Meesup, "The Flipped Classroom Approach Through A Google Sites and Project Based Learning on Creative Thinking And Innovation in The 21st Century," Rajabhat J. Sci. Humanit. Soc. Sci., vol. 21, no. 1 , pp. 205-223, 2020. 